\title{
SILSILAH DAN CORAK TAREKAT SYATARIYAH BENGKULU
}

\author{
Murkilim \\ Ismail \\ Ahmad Abas Musofa \\ Bobi Aidi Rahman*
}

\begin{abstract}
Abstrak
Masuknya Islam ke Bengkulu mengenai dari mana asalnya, siapa penyebarnya dan kapan masuknya, dapat diklasifikasikan menjadi beberapa teori, yaitu pertama teori Aceh, kedua teori Palembang, teori Minangkabau dan teori Banten. Dari daerah Minangkabau menjadi asalnya tarekat naqsyabandiyah dan syatariyyah. Tarekat syatariyyah melalui jalur Syekh Burhanudin Ulakan muridnya Syekh 'Abd al-Rauf Singkili. Tarekat syattariyah Bengkulu dibawa dari Minangkabau dan perkembanganya terlihat dari jumlah jamaah tarekat dan amalan-amalan syattariah di masjid-masjid tua. Keberadaan tarekat ini dapat ditelusuri dari jamaah dan pimpinannya yang ada di Kota Bengkulu. Jalur masuknya Tarekat Syatariyah yang ada di Kota Bengkulu melalui Tuangku Yasrul Faqih dan jalur kedua melalui H. Ali Amran Tuangku Bagindo Marajolela. Ajaran yang terkait paham wahdatul wujud tidak ada di Bengkulu yang ada adalah paham wahdatul syuhud. Motif dan pengaruh dalam bertarekat adalah untuk meningkatkan amal ibadah, menumbuhkan kebersamaan dan membangkitkan solidaritas sosial.
\end{abstract}

Kata Kunci : Eksistensi, Tarekat Syattariyah, Kota Bengkulu.

\section{Pendahuluan}

Proses islamisasi nusantara melahirkan beberapa teori diantaranya teori Arab dan teori India yang masingmasing teori memiliki argumentasi baik bersumber dari naskah atau artefak yang terlacak. Salah satu hal yang diperdebatkan adalah mengenai para penyebar Islam apakah para pedagang, duta besar atau sufi. Mengenai hal tersebut A. H. Johns berpendapat kecilnya kemungkinan para pedagang memainkan peranan terpenting dalam penyebaran
Islam, ia mengajukan bahwa para sufi pengembara yang terutama melakukan penyiaran Islam di kawasan Nusantara. Para sufi ini berhasil mengislamkan sejumlah besar penduduk Nusantara setidaknya sejak abad ke-13 M. Faktor utama keberhasilan konversi adalah kemampuan para sufi menyajikan Islam dalam kemasan atraktif, khususnya menekankan kesesuaian dengan Islam atau kontunuitas, ketimbang perubahan dalam kepercayaan dan praktik 
keagamaan lokal. Dengan menggunakan tasawuf sebagai sebuah kategori dalam literatur dan sejarah Melayu-Indonesia, Johns memeriksa sejumlah sejarah lokal untuk memperkuat hujahnya. ${ }^{1}$

Secara kelembagaan tarekat baru terbentuk sebagai organisasi dalam dunia tasawuf pada abad ke $8 \mathrm{H}$. Artinya, tarekat bisa dianggap sebagai hal baru yang belum dijumpai pada periode awal Islam, termasuk pada masa Rasulullah SAW. Tidak heran kemudian jika hampir semua jenis tarekat yang dikenal saat ini selalu dinisbatkan kepada nama-nama para wali atau ulama belakangan yang hidup berabad-abad dari Nabi Muhammad SAW.

Dan dalam perkembangannya di Indonesia terdapat 45 tarekat mu'tabarah, yaitu: Rumiyah, Rifa'iyah, Sa'diyah, Bakriyah, Justiyah, Umariyah, Alawiyah, Abasiyah, Zainiyah, Dasuqiyah, Akbariyah, Bayumiyah, Malamiyah, Ghoibiyah, Tijaniyah, Uwaisiyah, Idrisiyah, Samaniyah, Buhuriyah, Usyaqiyah, Kubrowiyah, Maulawiyah, Jalwatiyah, Baerumiyah, Ghozaliyah, Hamzawiyah, Hadadiyah, Mabuliyah, Sumbuliyah, Idrusiyah, Usmaniyah, Syadziliyah, Sya'baniyah, Khalsyaniyah, Qodiriyah, Syatoriyah, Khalwatiyah, Bakdasiyah, Syuhriyah, Ahmadiyah, 'Isawiyah, Thuruqil Akabiril Auliya,
Qadariyah wa Naqsabandiyah, Khalidiyah wa Naqsabandiyah, Ahli Mulazamatil Qur'an wa Sunnah wa Dalailil Khoiroti Wata'limi Fathil Qoribi, au Kifayatil Awam. $^{2}$

Masuknya Islam ke Bengkulu mengenai dari mana asalnya, siapa penyebarnya dan kapan masuknya, dapat diklasifikasikan menjadi beberapa teori, yaitu pertama teori Aceh, kedua teori Palembang, teori Minangkabau dan teori Banten. Pertama, teori Aceh berdasarkan argumentasi bahwa Islam dibawa ulama dari Aceh bernama Tengku Malin Muhidin tahun 1417 M ke Kerajaan Sungai Serut dan melalui dominasi Aceh dalam perdagangan rempah-rempah abad ke-17 serta di situs makam Gresik Dusun Kaum Gresik, Desa Pauh Terenjam, Kecamatan Mukomuko terdapat sembilan buah makam, dua diantaranya menggunakan nisan tipe Aceh. Kedua, teori Palembang berdasarkan argumentasi bahwa Islam dibawa Kesultanan Palembang dibuktikan dengan pengakuan masyarakat sebagai keturunan dari Kesultanan Palembang dan di wilayah Rejang Lebong terbukti ditemukannya piagam Undang-Undang dari tembaga dengan aksara Jawa Kuno, yang berangka tahun 1729 Saka atau 1807 Masehi Kesultanan Palembang dan hubungan kerajaan Palembang Darussalam dengan Raja Depati Tiang 
Empat di Lebong. Ketiga, teori Minangkabau berdasarkan argumentasi bahwa Islam masuk melalui perkawinan Sultan Muzaffar Syah, Raja dari Kerajaan Indrapura dengan Putri Serindang Bulan, puteri Rio Mawang dari Kerajaan Lebong (1620-1660), datangnya Bagindo Maharaja Sakti dari Kesultanan Pagaruyung abad XVI dan menjadi Raja Sungai Lemau dan kesultanan muko-muko di bawah pengaruh Kesultanan Indrapura Minangkabau. Keempat, teori Banten melalui persahabatan antara Kerajaan Banten dengan Kerajaan Selebar dan perkawinan antara Raja Pangeran Nata Di Raja dengan Putri Kemayun, puteri Sultan Ageng Tirtayasa dari Banten (1668). Diantaranya ulama yang berdakwah adalah Imam Maulana Ichsad (tahun 1336), Syekh Abdurrahman Batu Ampar (w. 1336 M), Syech Mutla, Tengku Malim Muhidin (1417), Imam Padang, Syech Muhammad Alim, Syech Abdur Rahman, Syekh Muhammad Amin, Syekh Abdul Latief (1917), Abdul Syukur (1527), Said Hadi al-Jafri, Kyai Haji Abdul Hamid Merogan, Haji Abdurrahman Delamat, KH. Husein, Syeikh Radhi, Sayid Ahmad, Haji Wahid dan Syech Ali. ${ }^{3}$ Syekh Abdul Latief (1917) sendiri mursyid Tarekat Naqsyabandiyah.
Di Kota Bengkulu di antaranya berkembang beberapa tarekat yaitu pertama; tarekat SyÂdziliyah yang dinisbatkan ke pendirinya yaitu Abû alHasan al-Syâdzilî yang mulai berkembang di wilayah Tunisia, Mesir, Aljazair, Sudan, Suriah, Semenanjung Arabia, dan sampai di Indonesia khususnya diwilayah Jawa Tengah dan Jawa Timur. Kedua; tarekat Syattâriyah yang dinisbatbatkan kepada Syaikh 'Abd Allah al-Syaththari, dan penyebaran pertama kali yaitu di India sekitar abad ke 12-16-an, kemudian di Melayu-Indonesia dipopulerkan oleh Abdurrauf al-Sinkili (Aceh). Ketiga; tarekat Sammâniyah yang didirikan oleh Muhammad bin 'Abd al-Kârim al-Madani al-Syâfî'î al-Sammân. Menurut sejarahnya Tarekat ini memiliki pengikut massal di Nusantara pada akhir abad ke-16 di Aceh. Keempat; tarekat Naqsyabandiyah dengan pendiri tarekat yaitu Muhammad bin Muhammad Baha' al-Din al-Uwaisi al Bukhari Naqsyabandi. Tarekat ini pertama kali berdiri di Asia Tengah kemudian meluas ke-Turki, Syuriah, Afganistan, India dan kemudian berpengaruh ke Indonesia Sekitar Abad 10-16 M.4

Fenomena Islam Bengkulu yang beberapa kalangan dianggap sebagai "Islam periferi," “Islam Ktp," “Islam transit" dan "Islam keturunan" menarik di 
teliti ketika tarekat masuk ke Bengkulu. Tarekat yang dalam pengamalannya melantunkan dzikir-dzikir dan tuntas dalam pengamalan rukun Islam menarik untuk dikaji dengan bagaimana mursyid atau tarekat mempengaruhi dalam praktik pengamalan keagamaan. Sehingga peran yang diberikan tarekat akan memperlihatkan eksistensinya dalam proses pribumisasi islam. Oleh sebab itu menarik untuk diteliti dengan judul “Eksistensi Tarekat Syattâriyah di Kota Bengkulu Tahun 1985-2015.

\section{A. Asal Usul dan Berkembangnya}

\section{Tarekat Syatariyah di Kota Bengkulu}

Jejak tarekat syatariyah di Kota Bengkulu dapat di amati pada masjidmasjid tua tepatnya praktek amalan dzikir setelah sholat fardu. ${ }^{5}$ Tetapi ada musholla khusus yang memang didirikan oleh para jamaah tarekat syatariyah yaitu Musholla Surau Rumbio yang dijadikan tempat pengajian setiap minggu oleh para jamaah.

Keberadaan tarekat ini dapat ditelusuri dari jamaah dan pimpinannya yang ada di Kota Bengkulu. Berikut ini jalur masuknya Tarekat Syatariyah yang ada di Kota Bengkulu yaitu

1. Jalur pertama masuknya tarekat Syattariyah ke Kota Bengkulu: ${ }^{6}$

a. Tuangku Yasrul Faqih, dia di-talqin oleh gurunya, b. Syaikh Ali Imran bin Hasan, dia di-talqin oleh gurunya,

c. Syekh Hasan bin M. Rahim Tuangku Bagindo Ringan-ringan Pakandangan, dia di-talqin oleh gurunya,

d. Syekh M. Yasin Qadhi Koto Tujuah Malin Mandaro, dia di-talqin oleh gurunya,

e. Syekh Ismael Padang Gantiang, dia di-talqin oleh gurunya,

f. Syekh M Shalih Talawi, dia ditalqin oleh gurunya,

g. Syekh Cupak, dia di-talqin oleh gurunya,

h. Syekh Qadhi Padang Gantiang, dia di-talqin oleh gurunya,

i. Syekh Burhanudin Ulakan, dia ditalqin oleh gurunya,

2. Jalur kedua masuknya tarekat Syattariyah ke Kota Bengkulu: ${ }^{7}$

a. H. Ali Amran Tuangku Bagindo Marajolela

b. Syeikh H. Ungku Panjang Sungai Janih

c. Syeikh Tuangku Sidi Batang Cino

d. Syeikh Tuangku Panjang-Sei-Sarik VII Koto

e. Syeikh Tuangku Kiambang Sicincin

f. Syeikh Tuangku Aluma di Koto Tuo Kab Agam

g. Syeikh Malalo Limo Puluh di Lima Puluh

h. Syeikh Shultan al-Kusai Ulakan

i. Syeikh Abdul Rahman Ulakan

j. Syekh Burhanudin Ulakan, dia ditalqin oleh gurunya

Sedangkan jalur Syekh Burhanudin Ulakan yaitu ${ }^{8}$

a. Syekh Burhanudin Ulakan, dia ditalqin oleh gurunya 
b. Syekh 'Abd al-Rauf singkili, dia ditalqin oleh gurunya

c. Al-'Arif bi Allah al Kamil alMukammil Shafiya al-Din Ahmad ibn Muhamad al-Madani alAnshari al-Syahir bi al-Qusyasyi, dia di-talqin oleh gurunya,

d. Abi al-Mawahib Abd Allah bin Ahmad bin Ali al-quraisyi al-Abasi al-Tsanawi, dia di-talqin oleh gurunya,

e. Sulthan al-'Arifin bi Allah al-Sayd Shibghat Allah, dia di-talqin oleh gurunya,

f. Qudwat al-`Ulama Wajih al-Din al-'Alawi, dia di-talqin oleh gurunya,

g. Al- Ghawts al Jami' li al-Jawami' al-Sayd Muhamad al-Ghawts, dia di-talqin oleh gurunya,

h. Qudwat al-Muqarrabin al-Syaikh Haji Hudur Thaba Tsarahu (semoga dibaikkan Allah akan kuburnya) dia mengambil dari gurunya,

i. Al-Syaikh Hidayatu Allah alSarmasti, dia di-talqin-kan oleh gurunya,

j. Al-Imam Qadhi al-Syaththari, dia di-talqin-kan oleh gurunya,

k. Al-Syaikh Abd Allah al-Syaththari, dia di-talqin-kan oleh gurunya,

1. Muhamad 'Arif, dia di-talqin-kan oleh gurunya,

m. Muhamad 'Asyiq, dia di-talqin-kan oleh gurunya,

n. Al-Syaikh Khudaqali al-Mawara al Nahar, ia di-talqin-kan oleh gurunya,

o. Al-Quthub Abi al-Hasan alHirqani, dia di-talqin-kan oleh gurunya, p. Al-Syaikh Abi al-Muzhafar Maulana Turki al-Thusi, dia ditalqin-kan oleh gurunya,

q. Al-Syaikh al-'Arabiy Yazid al'Isyqy, dia di-talqin-kan oleh gurunya,

r. Al-Syaikh Muhamad al-Magribi, dia di-talqin-kan oleh gurunya,

s. Ruhaniyah Sulthan al-'Arifin Abi Yazid al-Bistami, dia di-talqin-kan oleh gurunya,

t. Ruhaniyah al-Imam Ja'far alShadiq, di-talqin-kan oleh gurunya,

u. Al-Imam Muhamad al-Baqir, dia di-talqin-kan oleh gurunya,

v. Al-Imam Zain al-'Abidin, dia ditalqin-kan oleh gurunya,

w. Al-Imam Husayn al-Syahid, dia ditalqin-kan oleh gurunya,

x. Al-Imam al-Murthadha 'Ali bin Abi Thalib, Radhiya Allah 'anhu, dia di-talqin-kan oleh gurunya,

y. Nabi Muhamad Saw.

Dari dua jalur masuknya tarekat syatariyyah tersebut semuanya berasal dari Minangkabau tetapi ada perbedaan waktu antara jalur pertama dengan jalur kedua. Jalur Tuangku Syahrul Tanjung menyebutkan pengajian tarekat syatariyyah di mulai sekitar tahun 1987.9

Jalur Tuangku Ali Amran memulai pengajian tarekat syatariyah di Bengkulu Utara tepatnya di Pesantren Dinnul Ma'ruf sekitar 1979, sedangkan di Kota Bengkulu di mulai tahun 2000-an. 
Pada awalnya pengajian rutin di lakukan dari rumah ke rumah, setelah itu diadakan musyawarah dengan para jamaah maka disepakati pembangunan tempat pengajian di KM 8 yang bernama Surau Rumbio atau Dinnul Ma'ruf Surau Rumbio. Surau Rumbio ini di bangun tahun 2000 dan selesai pada tahun 2002.10

Setelah Surau Rumbio di bangun, banyak jamaah pengajian yang menanyakan tentang tarekat dan Tuangku Panjang telah memberi izin, maka Tuangku Ali Amran mulai mengajarkan Tarekat Syatariyyah kepada jamaah pengajian. Dalam pembukaan pengajian Tuangku Ali Amran memulainya dengan pengajian diri. Hingga sekarang jumlah anggota tarekat syatariyyah sekitar 80 orang yang dipusatkan di Masjid Baitul Makmur Rawa Makmur berjumlah 30 orang dan di Surau Rumbio berjumlah 50 orang. ${ }^{11}$

\section{B. Ajaran Tarekat Syatariyah di Bengkulu}

Dalam prakteknya ilmu tarekat tidak di ajarkan kepada semua jama'ah pengajian tetapi bagi yang meminta baru diajarkan yang diawali dengan proses baiat. Baiat itu akan di lakukan setelah calon anggota mempunyai pengetahuan tentang konsep dasar dirinya sendiri dan mempunyai kehendak yang kuat.

Dalam pelaksanaan baiat ada beberapa alat-alat yang dipersiapkan, yaitu Kain Putih (Ganiah), Pisau, Cermin dan Piring. Makna kain putih adalah hakekatnya untuk membersihkan diri, pisau di asah supaya tajam ilmu dan kaca supaya tampak siapa di dalam kaca dan siapa yang berkaca.

Berikut ini ajaran-ajaran dalam Tarekat Syatariyah di Bengkulu yaitu: ${ }^{12}$ Pertama, ajaran yang bersumber dari kitab Syifaul Qulb yaitu:

1) Menetapkan awal Ramadhan dan Syawal dengan Ruqyatul Hilal

2) Menetapkan Ruqyatul Hilal dengan Hisab Taqwim Khamisah

3) Tarwih dua puluh rakaat dengan sepuluh salam

4) Witir tiga rakaat dengan dua salam

5) Melafazkan niat sedikit sebelum takbir

6) Membaca Do'a Iftitah

7) Membaca Basmallah, di Fatihah

8) Tasbih pada Ruku' pada Sujud $3 X$

9) Qunut pada rakaat kedua Salat Subuh sesudah Ruku'

10) Tasbih dan Dzikir sesudah Salat Fardu

11) Khutbah Jumat dan dua Hari Raya dengan Bahasa Arab

12) Dzikir, Do'a, dan bacaan Quran manfaat bagi orang Mukmin yang telah mati

13) Talqin 
14) Berharum-harum sebelum do'a Arwah Qurban dan 'Aqiqah dengan membakar kemenyan

15) Ziarah Qubur Nabi Saw. Dan Ulama

16) Tawassul

17) Menutup kepala bagi laki-laki waktu Shalat

18) Membesarkan Maulud Nabi Saw. Dengan syair Syarafal Anam

19) Madzhab Syafi'i

20) Bai'ah

21) Khatimah

Kedua, ajaran yang bersumber dari kitab duqoiqul akbar yaitu

Diantara ajaranya adalah tentang martabat yang tujuh yang didalam Surah At-Tin, "sesungguhnya aku ciptakan manusia sebaik-baiknya". Pembahasan martabat yang tujuh seperti materi asal kejadian kita, Adam dijadikan dari tuhan, Hai, Jibril ciptakan Adam. Ambilkan dari sifatku melahirkan api, melahirkan angin, melahirkan tanah. Ambilkan dari di aduk. Bentuk seperti apa wahai Tuhanku, kalau ingin tahu bentuknya sujudlah jibril dalam sujud itulah ia diperlihatkan oleh Allah. Hai Jibril, hai Izrail tiupkan roh kedalam tubuhnya akan kujadikan khalifah. Kemudian ditiupkan oleh roh, di pancing oleh tuhan burung berdua, dia seorang saja itu jadilah Hawa. Diambilkan dari tulang rusuk sebelah kiri, sepasanglah si Adam dan Hawa itulah dari martabat yang tujuh. Sehari semalam di kandung ibu martabatnya hayat, zikirnya menunjukkan dia hidup dengan zatnya. Tiga hari tiga malam di kandung ibu martabatnya hayat, bacaan (pujinya) menunjukkan dia hidup dengan rahasianya. Tujuh hari tujuh malam dikandung Ibu martabatnya qudrat, bacaannya (ucapannya) di dalam tujuh hari itu Al-haq, Al-haq, Al-haq. Menunjukkan dia hidup dengan nur-Nya. Empat puluh hari empat puluh malam nama martabatnya iradat, ucapannya subhanallah menunjukkan dia hidup dengan roh-Nya, pada empat puluh hari empat puluh malam inilah sang ibu mulai gelisah. Tiga bulan martabatnya sami' pujinya Alhamdulillah. Tujuh bulan martabatnya basar, menunjukkan dia hidup dengan rupa-Nya. Sembilan bulan dikandung bundo martabatnya qalam, ucapannya laa ilaa ha illallah, itulah zikirnya di dalam kandungan ibu. Martabat yang tujuh atau sifat ma'ni atau di sebut juga di tempat lain anggota yang tujuh martabat yang tujuh itulah yang diajarkan satari itu hayat, ilmu, qodrat, iradat, sami', basir, dan qalam. Hayat di Allah jantungnya di kita, ilmu di Allah kepala di kita, qodrat di Allah tulang di kita, iradah di Allah nafasnya di kita, sami' di Allah talingoe diawak, basir di Allah matoen diawak, qalam di Tuhan 
mancunge di kito. Angguato nan tujua. Angguato nan tujua sifat ma'ani orang itu tunggu-nemunggu, berdekatan. Saya dekat dari dirinya, tidak dapat dibantahkan. ${ }^{13}$

Selesai memberi salam dari setia sholat wajib sanagat diajurkan untuk memperbanyak zikir dan istigfar. Sehubungan dengan itu 'Abd al-Rauf mencoba mengurutkan apa yang seharusnya di baca itu, ${ }^{14}$ yaitu:

1) Membaca istigfar, yaitu: astagfir allah al-azhim allazi la ilaha ila huwa alhayyu al-qayyum wa atubu ilayhi, 3 kali

2) Membaca allahuma anta al-salam sampai akhir.

3) Membaca surah al-fatihah sampai akhir

4) Membaca wa ilahukum (albaqorah;163)

5) Membaca allahuma inni aqdamu ilayka bayna yadayya kulla nafsin wa lahzhatin ahlu al-summawati wa ahli al-ardhi min kulli inni aqdamu ilayka bayna yadayya dzalika kullihi.

6) Membaca ayat kursi (al-baqorah;255)

7) Membaca syahida allah (Ali-imran; 18)

8) Membaca inna al-dina 'inda allah al-islam (awal ayat 19 Ali-Imran)

9) Membaca wa ana asyhadu bima syahida allah bihi wa as tawda'u allah hadzihi al-syahadat wa hiya li 'inda allahi wady' at

10) Membaca qulli Allahumma (AliImran 26,27)

11) Membaca allahuma ya rahmana aldunya wa al-akhirat, rahymuhuma rahmmani anta tarhamani farhamni birahmatin min 'indika tagnini biha 'an rahmatin min siwaka

12) Membaca tasbi, tahmid, takbir dan sholawat

13) Membaca la ilaha illa allah 10 kali dan di akhiri muhamadun rasulullah, kemudian berdo'a.

a. Zikir, istighfar pada waktu tertentu

1. Membaca la ilaha illa allah, sebanyak 1000 kali pada saat selesai sholat isya, sholat tahajjud dan sholat subuh.

2. Membaca istigfar sebanyak 100 kali pada saat selesai sholat isya, sholat tahajjud dan sholat subuh.

3. Membaca tasbih selesai sholat duha, sebelum terbit allahi wa alhamduli allahi wa la ilaha illa allah wa allahu akhbar wa lahawla wala quwwata illa billahi al-'aliyi alal'azim, 10 kali. ${ }^{15}$

Demikian lah beberapa wirid yang sebaiknya dilakukan oleh seorang salik guna tercapainya taqarrub kepada Allah SWT. Di lihat materi wirid tersebut, 'Abd al-Rauf lebih cendrung pada ibadah- 
ibadah yang tidak banyak memakan waktu dan waktu yang di pilihnya waktuwaktu yang tidak produktif dan tidak mengganggu akan aktivitas setiap hari. Dan 'Abd al-rauf lebih banyak mengutamakan wirid-wirid membaca alqur'an dari yang lainnya, sebagaimana yang diketahui abhawa al-qur'an itu adalah kalam allah. Disamping itu 'Abd al-Rauf juga memili ayat-ayat atau suratsurat yang mengandung makna dan faedah guna keselamatan di dunia in, hal ini berarti, sekali merangkuh dayung dua tiga pulau terlampaui, sekali membuka puro dua tiga hutang terbayar, artinya dengan membaca wirid-wirid itu akan menghasilkan rasa dekat dengan allah, dan akan mendapat pahala di akhirat kelak dan semoga bisa membuka kan pintu untuk tercapainya suatu hajad atau keperluan.

Adapun etika dzikir itu adalah: lima hal sebelum dzikir, dua belas hal saat melakukan dzikir dan tiga hal lagi setelah selesai mengerjakan dzikir tersebut. Adapu lima hal yang harus dilakukan sebelum dzikir: taubat, mandi atau berwudhu, berkosentrasi untuk meleh keyakinan, meminta pertolongan syeikh serta menyakini bahwa bantuan dari syekhnya itu sama dengan bantuan nabi SAW, karena syeikh adalah penggantinya.
Sedangkan dua belas hal yang harus dilakukan saat mengerjakan dzikir adalah: duduk di tempat yang suci, meletakan kdua belah tangan pada kedua paha, berwangi-wangian di tempat dzikir, memakai pakaian yang baik, memilih tempat yang sunyi, memejamkan kedua mata, membayangkan syekhnya, jujur dalam dzikir, ikhlas, memilih kalimat lai illaha illa Allah untuk bacaan dzikir, menghadirkan (23 makna dzikir, dan meniadakan segala wujud selain Allah dari dalam hati. adapun tiga hal yang harus dilakukan setelah dzikir adalah: tenang jika sedang diam, mengatur napas secara berulang-ulang serta tidak minumair sesudahnya. Demikianlah dan hanya kepada Allah kita memohon pertolongan.

Adapun tata cara dzikir itu cukup banyak, dan dapat diketahui atas bimbingan syekh, jangan sampai mempelajari tanpa bimbingan syeikh, karena ada satu keterangan mengatakan bahwa barangsiapa yang belajar tanpa syeikh maka setanlah yang menjadikan syekhnya. Oleh karenanya carilah syekh yang sempurna dan mampu menyempurnakan, bersungguh sungguhlah dalam mencarinya, karena barang siapa yang bersungguh-sungguh, niscaya dia akan memperoleh apa yang 
dicarinya, bersikap sopanlah kepadanya, dan satukanlah kendakmu dengan kehendaknya, sehingga engkau tidak menghendaki sesuatu kecuali apa yang dikehendakinya. Dengan demikian, berkat izin Allah niscaya engkau akan mencapai tauhid yang dicari semua orang yang berusaha mencapai hakikat Allah dan hanya kepadalah kita memohon pertolongan. Kemudian, ketahuilah wahai murid, tata cara dzikir seperti tersebut dia tasa berasal dari syaidina Ammirrul Mukmini, Ali bin Abi Thalib-semoga Allah memuliakan wajahnya-ketika beliau mengemukakan kepada Nabi Saw tentang kerinduan, kecintaan serta kesungguhan untuk sampai kepada hakikat Allah, yang Esa dan Perkasa. Saat itu Nabi mengajarkan (24) tata cara dzikir seperti yang terdapat dalam berberapa hadisnya. Ali bertanya, “ ya Rasullulah tunjukanlah kepadaku cara terdekat untuk mecapai hakikat Allah Ta'ala, termudah bagi hambanya, serta terbaik di sisinya!" maka Rasulullah Saw menjawab, " engkau harus membiasakan dzikir di tempat yang sepi". Ali bertanya lagi:" bagaimana aku berdzikir ya Rasulullah?" Nabi Saw menjawab:" pejamkanlah kedua matamu dan dengarlah ucapanku", lalu Nabi Saw mengucapkan kalimat la illaha illa Allah 3 kali dan Ali mendengarkanya. Setelah itu ali mengucapkan yang tadi tersebut, sedangkan Nabi Saw mendengarkanya, sekian.

Cara melaksanakan dzikir itu ada dua, yaitu dzikir nyaring dan dzikir pelan adapun dzikir nyaring, caranya bermacam-macam, antara lain dengan dengan cara pengingkaran (nafyi) dan penegasan (isbat) yaitu dengan mengucapkan kalimat la illaha illa Allah. cara yang lai isbat saja. Yaitu dengan mengucapkan kalimat illa Allah, illa Allah kemudian dengan menyebut isim (nama) dzat saja, yaitu kata Allah, Allah. Masingmasing model tersebut memiliki tata caranya sendiri. Diantara dzikir nyaring yang lain adalah ucapan $\mathrm{Hu} \mathrm{Hu}$ (dia), atau $\mathrm{Hu}$ Allah, $\mathrm{Hu}$ Allah, atau Allah Hu, Allah Hu. ${ }^{16}$ Guru kami semoga Allah memberi rahmat karena kemulianya, memberi penjelasan dalam kitab (25) Dau' al-Halah tentang dzikir Hu dan lapaz Allah tesebut: ketahuilah bahwa Ism al-a'zam (nama agung) hu allah adalah zikir gaib dalm kesaksian, zikir allahu adalah zikir kesaksian dalam kegaiban, zikir allah allah adalah zikir kesaksian dalam kesaksian secara terperinci, sedangkan zikir hu hu adalah zikir gaib dalam kegaiban secara globa sekian. Semua zikir di atas juga bnyak carany yang dapat diketahui berdasarkan bimbingan Syekh.

Adapun pada zikir pelan ada tiga cara. Pertama dengan mengatur nafas, 
yaitu dengan membayangkan kalimat pertama (la illaha) pada waktu masuknya nafas. Mengenai tata cara mengatur nafas dan membayangkan kalimat tauhid selengkapnya dapat diketahui atas bimbingan syekh. Dalam kitab al-jawahir, Muhamad al-gaus- semoga allah memberi kita rahmad karena kemuliaan dan ilmunya- mengatakan, “zikir la ilaha illa Allah adalah untuk melepaskan diri dari alam kemanusiaan (an-nasut), sehingga tampaklah alam samawi (al-malakut) dengan mengingkari segala sesuatu selain Allah, dan menegaskan zat-nya saja. Zikir allah allah untuk dapat mencapai tingkat alam kemaha perkasaan atau kemaha kuasaan (Aljabarut), dan beraklahlah dengan akhlak allah.zikir Allah hu untuk dapat mencapai (26) sifat ketuhanan altahut, dan tidak ada sesuatupun yang menyertai allah. Zikir huhayyun untuk dapat menyaksikan hal yang gaib, (Firman allah) "kami akan memperlihatkan kepada mereka tanda tanda (kekuasaan) kami disegenap penjuru dan pada dirimereka sendiri". Sedangkan zikir yang lainnya un tuk meniadakan sesuatu yangmungkin ada, dan menetapkan sesuatu yang wajib adanya. (zikir) huwa al-zahir (dia yang lahir), huwa al-batin (dia yang batin) untuk menghilangkan keduaan, dan melihat hal gaib menjadi nyata. (zikir) huwa al-awwal (dia yang pertama) huwa al-akhir (dia yang terakhir) untuk mengikat alam azali dan abadi, sekian. Cara zikir yang kedua dalam zikir pelan adalah zikir hati, dan yang ke tiga adalah zikir istila', yang tatacaranya dapat diketahu dari mursyid, (pembimbing), hanya kepada allah lah kita memohon petunjuk

\section{Motif Pengaruh Tarekat Syatariayah bagi Pengamalnya dan Masyarakat di Kota Bengkulu}

Dalam praktek keagamaan khususnya dalam bertarekat seseorang memiliki pengalaman spiritual yang berbeda baik bagi para jamaah yang mengikuti tarekat ataupun yang belum. Diantaranya ada beberapa latar belakang yaitu

\section{Pertama:}

Kini itu dalam hakekat hati kita yang paling dalam, sebab ibaratnya kita kini sebuah perjalanan dari Padang ke Bengkulu baik berjalan kaki, mobil, motor, maupun pakai pesawat. Tapi yang namanya satary itu jalan ke tuhan, intinya masuk satary itu ndak mencari jalan sampai ketuhan baik zahir maupun batin.

Tidak berkira-kira kini ko setelah awakko mempelajari tarekat satary 
jalan ke tuhan insyaallah mudahmudahan sehingganya lah hilang perasaan alamko koko berat dibuat. ${ }^{17}$

Kedua:

Pertama sekali, sebelunya itu ada kegelisaan jiwa. Setelah adanya masuk tarekat satary tersebut sudah ada kemantapan jiwa. Jadi motivasinya untuk mencari kemantapan/ketenangan jiwa dalam hidup berhubungan dengan tuhan.

\section{Ketiga:}

Pertama mantap pendirian, istilahnya kemantapan jiwa sudah masuk sekali, contohnya biasanya sebelum masuk tarekat satary kalo sembayang biasanya agak gelisah, malas setelah masuk tarekat satary ko kini sembayang kini nan tenang. Jadi intinya ada di dalam diri sendiri kalau kita sudah paham akan ilmu itu kita juga pasti akan mengerti. 18

Lahirnya tasawuf sebagai fenomena ajaran Islam, diawali dari ketidakpuasan terhadap praktik ajaran Islam yang cenderung formalisme dan legalisme serta banyaknya penyimpangan-penyimpangan atas nama hukum agama. Selain itu, tasawuf juga sebagai gerakan moral (kritik) terhadap ketimpangan sosial, moral, dan ekonomi yang ada di dalam umat Islam, khususnya yang dilakukan kalangan penguasa pada waktu itu. . Pada saat demikian tampillah beberapa orang tokoh untuk memberikan solusi dengan ajaran tasawufnya. Solusi tasawuf terhadap formalisme dengan spiritualisasi ritual, merupakan pembenahan dan elaborasi tindakan fisik ke dalam tindakan batin. Faktor internal lainnya ialah terjadinya pertikaian politik intern umat Islam yang menyebabkan perang saudara yang dimulai antara Ali bin Abi Thalib dengan Mu'awiyah bermula darial-fitnah alkubrayang menimpa khalifah ketiga, Usman bin Affan maka sebagian tokoh agama mengambil jarak dengan kehidupan politik dan sosial.

Saat ini kita berada di tengah-tengah kehidupan masyarakat modern, atau sering pula disebut sebagai masyarakat yang sekuler. Pada umumnya, hubungan antara anggota masyarakatnya atas dasar prinsip-prinsip materialistik. Mereka merasa bebas dan lepas dari kontrol agama dan pandangan dunia metafisis. Dalam masyarakat modern yang cenderung rasionalis, sekuler dan materialis, ternyata tidak menambah kebahagiaan dan ketentraman hidupnya. Berkaitan dengan itu, Sayyid Hosein Nasr menilai bahwa akibat masyarakat modern yang mendewakan ilmu pengetahuan dan teknologi, berada dalam wilayah pinggiran eksistensinya sendiri. Masyarakat yang demikian adalah 
masyarakat Barat yang telah kehilangan visi keilahian. Hal ini menimbulkan kehampaan spiritual, yang berakibat banyak dijumpai orang yang stress dan gelisah, akibat tidak mempunyai pegangan hidup.

Untuk mengantisipasi hal-hal semacam di atas, maka diperlukan Keterlibatan langsung tasawuf dalam kancah politik dan ekonomi, hal ini dapat kita lihat dalam sejarah Tarekat Sanusiyah di berbagai daerah di Afrika Utara, Dalam kiprahnya, tarekat ini tidak henti-hentinya bekerja dengan pendidikan keruhanian, disiplin tinggi, dan memajukan perniagaan yang menarik orang-orang ke dalam pahamnya. Maka Fazlur Rahman menceritakan bahwa tarekat ini menanamkan disiplin tinggi dan aktif dalam medan pejuangan hidup, baik sosial, politik, dan ekonomi. Pengikutnya dilatih menggunakan senjata dan berekonomi (berdagang dan bertani). Gerakannya pada perjuangan dan pembaharuan, dan programnya lebih berada dalam batasan positivisme moral dan kesejahteraan sosial, tidak "terkungkung" dalam batasan-batasan spiritual keakhiratan. Coraknya lebih purifikasionis dan lebih aktif, memberantas penyelewengan moral, sosial dan keagamaan, maka Fazlur
Rahman menamakannya sebagai NeoSufisme. Kebutuhan akan kekuatan ekonomi dan teknologi saat ini sangat diperlukan bagi penunjang keberhasilan umat Islam demi menjaga dan mengangkat martabat umat itu sendiri, kerena sudah banyak terbukti bahwa umat Islam sering dijadikan bulanbulanan oleh orang-orang kafir karena kelemahan mereka dibidang ekonomi yang akhirnya menjadikan mereka lemah dalam bidang teknologi dan politik, hal ini adalah suatu bahaya yang wajib dihilangkan dan dijauhi oleh orang-orang yang percaya terhadap Allah dan rasulnya

Kehidupan dalam beragama dipengaruhi oleh berbagai faktor termasuk diantaranya motif orang dalam bertarekat yang pada umumnya berpandangan agar dapat lebih mendekatkan diri kepada sang pencipta melalui pengamalan rutinitas berdzikir setelah sholat dan mengikuti pengajian. Jelasnya secara umum jamaah tarekat sejalan dengan konsep Neo-sufisme yang berpandangan sesungguhnya menghendaki agar umat Islam mampu melakukan tawazun (penyeimbangan) antara pemenuhan kepentingan akhirat dan dunia. Umat Islam harus mampu memformulasikan ajaran Islam dalam kehidupan sosial. Menurutnya, konsep ini 
mengandung dua arti yakni: pertama, mengembalikan tasawuf kepada bentuk keberagamaan masa Rasulullah, namun dengan tetap menerima kehidupan dunia dalam mendekati Tuhan. Kedua, mengembangkan potensi tasawuf dalam menghadapi perkembangan zaman dengan memanfaatkan pengalaman intuisi. Konsep tasawuf Neo-sufisme ini sering diterapkan oleh para ulama dalam ajaran tarekat, misalnya: Syattariyah, Tsamaniyah, dan lainnya. Melalui ajaran tarekat ini di Nusantara diajarkan bagaimana cara Islam melakukan pendekatan kepada Tuhan melalui pendekatan-pendekatan yang seimbang antara kehidupan dunia dan akhirat.

Jamaah dari Syekh Burhanuddin menganut mazhab dari Imam Syafi'i. Menurut salah seorang jamaah tarekat Syattariyah mengatakan bahwa ajaran dari tarekat Syattariyah adalah ajaran yang fleksibel dalam menyikapi dinamika keberagamaan umat serta menyikapi tradisi budaya lokal. Ajaran Sattariyah sangat berpengaruh terhadap tradisitradisi dari budaya Minang. Istilah orang Minang -Adaik Basandiang jo Syarak, Syarak Basandiang jo Kitabullah. Sehingga mereka tidak perlu meninggalkan tradisi budaya Minangkabau untuk menjalakan syariat. Sesuai dengan konsep yang dibangun oleh Syekh Burhanuddin yang 60 membuat ajaran tasawuf sejalan dengan syariat (Tasawuf Amali).

Kemampuan seseorang untuk mengenali atau memahami nilai agama yang terletak pada nilai-nilai luhurnya serta menjadikan nilai-nilai dalam bersikap dan bertingkah laku merupakan ciri dari kematanan beragama, jadi kematangan beragama terlihat dari kemampuan seseorang untuk memahami, menghayati serta mengaplikasikan nilainilai luhur agama yang dianutnya dalam kehidupan sehari-hari. Ia menganut suatu agama karena menurut keyakinannya agama tersebutlah yang terbaik. Karena itu ia berusaha menjadi penganut yang baik, keyakinan itu ditampilkannya dalam sikap dan tingkah laku keagamaan yang mencerminkan ketaatan terhadap agamanya.

Seperti halnya yang telah dijelaskan diatas dalam tingkat perkembangan yang dicapai diusia anak-anak, maka kedewasaan jasmani belum tentu berkembang setara dengan perkembangan rohani. Secara normal memang seorang yang sudah mencapai tingkat kedewasaan akan memiliki pola kematangan rohani seperti kematangan berpikir, kematangan pribadi maupun kematangan emosi. Tetapi perimbangan antara kedewasaan jasmani dan kematangan rohani ini ada kalanya tidak berjalan sejajar. Secara fisik 
(jasmani) seseorang mungkin sudah dewasa, tetapi secara rohani ia ternyata belum matang.

\section{Kesimpulan}

Munculnya tarekat syatariyah di Kota Bengkulu tidak terlepas dari masyarakat Minangkabau yang membawanya dari berbagai daerah di Sumatra Barat diantaranya yaitu Lubuk Alung, Malalo, kampung dalam Pariaman dan sekitarnya yang memang diketahui adalah termasuk basis tarekat syatariyah di Sumatera Barat. Kedatangan mereka ke Bengkulu tidak dapat dipisahkan dari latar belakang kebiasaan hidup orang Minangkabau yang suka pergi merantau.

Eksistensi tarekat syatariyah terlacak dari keberadaan para jamaah dan tuanku yang menjadi pemimpinya ataupun amalan yang masih berjalan di masjidmasjid tua yang ada di Kota Bengkulu. Di antaranya di masjid Syuhada, masjid atTaqwa, masjid al-Muhtadin, masjid alJihad dan lain-lain. Tapi ada musholla khusus yang didirikan para penganut tarekat syatariyah yaitu Surau Rumbio yang memang digunakan pula oleh para jamaahnya untuk mengadakan pengajian pada malam minggu setiap minggunya.

Pemahaman terhadap pemikiranpemikiran Syekh Burhanuddin oleh jamaah memang tidak sepenuhnya dipahami oleh jamaahnya, hal itu dikarenakan implementasi dari pemikiran Syekh Burhanuddin lebih dikuasai secara utuh oleh para tuanku. Namun kepada jamaahnya hanya diberi pemahaman akan ibadah/amal yang membuat mereka menjadi manusia yang lebih baik lagi dan melalui amalan-amalan menurut mereka sudah bisa mendekatkan diri kepada Tuhan, salah satunya adalah selalu berzikir kepada Allah.

Kegiatan berzikir oleh jamaah tarekat syatariyah dilakukan setelah sholat lima waktu dengan nama dzikir sepuluh, dzikir seratus, dzikir seribu yang disesuaikan dengan kesanggupannya masing-masing. Anggota tarekat secara umum memang banyak dari suku minagkabau walaupun ada juga dari penduduk asli Bengkulu baik Lembak, Serawai ataupun Rejang.

Tarekat Syatariyah yang eksis di Bengkulu cenderung melunakan ajaran wahdatul wujud dengan penguatan sifat dua puluh dan ada pula yang tidak mengakuinya hanya mengakui paham wahdatul syuhud. Rumusannya sudah lebih disesuaikan dengan dalil-dalil ortodoks Islam, sehingga doktrin Wahdat al-wujud ini lebih dapat diterima oleh banyak kalangan. Bahkan doktrin ini terkesan 
dilucuti, sehingga ajaran tarekat Syatariyah di Bengkulu, terutama yang berkembang pada abad 21 menjadi lebih khas tanpa mengajarkan doktrin Wahdat al-wujud seperti yang ada di Sumatra Barat, tetapi lebih penguatan terhadap sifat dua puluh

\section{Referensi}

1 Johns, A.H. "Sufsm as a Category in Indonesian Literature and History", JSEAH, 2, 1961. hlm. 10-23. Azyumardi Azra. Jaringan Ulama Timur Tengah dan Kepulauan Nusantara Abad XVII dan XVIII: Melacak Akar-Akar Pembaruan Pemikiran Islam di Indonesia, Prenada Media, Jakarta, 2013, hlm. 14-16.

${ }^{2}$ Muhsin Jamil, Tarekat dan Dinamika Sosial Politik (Tafsir Sosial Sufi Nusantara), Yogyakarta: Pustaka Pelajar, 2005, h.110. Sri Mulyani, hlm. 26253

3 Ahmad Abas Musofa. Sejarah Islam di Bengkulu abad ke XX M dalam jurnal Tsaqofah \& Tarikh Vol. 1 No. 2, Juli-Desember 2016. Bengkulu: IAIN Bengkulu, hlm. 115-121.

4Sri Mulyati, dkk. Mengenal dan Memahami Tarekat-tarekat Muktabarah di Indonesia, Prenada Media, Jakarta, 2004, hlm. 26-253.

5 Masjid-masjid tersebut ialah Masjid Syuhada di Dusun Besar, Masjid Taqwa di Jembatan Kecil, Masjid al-Muhtadiin di Jl Padang Jati, Masjid Babussalam di KM 8 dan Masjid alJihad Rawa Makmur.

6Wawancara dengan Yasrul tahun 2017

7Wawancara dengan Ali Amran tahun 2017. Ali Amran belajar tarekat di Sungai Janiah Negeri 7, Kecamatan 5 Koto Kampung Dalam Kabupaten Padang Pariaman.

8Syamsul Bahri, Tarekat Abd. al-Rauf Singkel dalam Tanbih al-Masyi, Hayfa Press, Padang, 2012, hlm. 41-42.

${ }^{9}$ Wawancara dengan Yasrul tahun 2017

10Wawancara dengan Ali Amran tahun 2017

11Wawancara dengan Ali Amran tahun 2017 